\title{
Effect of pattern of water supply on Vicia faba L. 4. Sim- ulation studies on yield variability
}

\section{GRASHOFF \& R. STOKKERS*}

DLO-Centre for Agrobiological Research, P.O. Box 14, NL 6700 AA Wageningen, Netherlands

Received 12 February 1992; accepted 10 August 1992

\begin{abstract}
The effects of water supply patterns on yield variability of Vicia faba L. were studied by means of a crop growth model. The model simulates crop dry matter production and soil water availability in dependence on plant characteristics and weather and soil data. Consequences of various weather conditions on growth were evaluated, using 4 data sets from various soils and sites in Westem Europe. In set 1 (14 years; heavy clay soil; Netherlands) and set 3 ( 2 years; 9 locations in Western Europe), linear regressions of measured versus simulated seed yields, fitted through the origin, had slopes of almost 1 and accounted for $68 \%$ (set 1 ) and $12 \%$ (set 3 ) of the yield variation. In both sets, these regressions accounted for about $80 \%$ of the variation, if deviations, due to damage effects of hail, lodging, and diseases were excluded (these damage effects are not calculated in the model). In set 1 , the average seed yield was $5.3 \mathrm{t} \mathrm{ha}^{-1}$ (measured and simulated) and the standard deviation (s.d.) was 1.3 (measured) and $1.5 \mathrm{t} \mathrm{ha}^{-1}$ (simulated). Simulated irrigation after the end of flowering (i.e. from grain filling onwards) stabilized yield (s.d. $\left.=0.4 \mathrm{tha}^{-1}\right)$ on a high level $\left(6.2 \mathrm{tha}^{-1}\right)$. Simulated irrigation during the whole season had almost no additional effect. The results for set 3 were similar to set 1 . Simulations for set 1 showed that the 'target' soil water contents during flowering for optimum final seed yields varied from $0.27-0.32 \mathrm{~cm}^{3} \mathrm{~cm}^{-3}$ for this soil type (pF-values of respectively 3 and 2.3), depending on temperature and air humidity. After flowering a water content higher than $0.32 \mathrm{~cm}^{3} \mathrm{~cm}^{-3}$ was required. Two strategies for breeding ideotypes were evaluated; doubling the rooted depth and root growth rate stabilized seed yields (the s.d. was reduced by $30 \%$ in set 1 ), but doubling the water extraction capacity of the crop had almost no effect. The model accounted for less than $1 \%$ of the variation in set 2 (14 years; light silty loam; Netherlands) and 4 (3 years; 5 regional experimental farms; Netherlands). This was different from set 1 and 3 and probably due to effects of capillary rise (in set 2) and diseases (in set 4), which are not included in the model. In set 4 , the yield gap between simulated and measured yields increased with observed disease attack in the field, from less than $1 \mathrm{t} \mathrm{ha}^{-1}$ with 'absent or low' attack to more than 3.5 with 'severe' attack. The simulation studies show how control of water availability stabilizes faba bean yields in many environments. They also indicate the importance of disease control and of breeding ideotypes with deeper rooting capacity.
\end{abstract}

Keywords: faba beans, Vicia faba L., simulation, modeling, water supply, yield variability

* Present address: Bulb Research Centre, P.O. Box 85, NL 2160 AB Lisse, Netherlands 


\section{Introduction}

Faba bean (Vicia faba L.) is a protein-rich seed crop and can be an alternative for imported soya bean residues as a raw material for the animal-feed compounding industry. Variability in yield is a major problem with this crop. In field experiments yield and dry matter partitioning were strongly affected by the amount and temporal distribution of water supply (Grashoff, 1990a, 1990b). Grashoff \& Verkerke (1991) showed that faba beans are inefficient in adapting to conditions of water shortage.

The objective of this paper is to investigate whether variation in natural water supply is a major cause of the yield variability of faba beans in Western Europe. A general crop growth simulation model was adapted for faba beans and used to analyse results of field experiments under various weather conditions, soil types and sites in Western Europe. Next the model was used to explore the possibilities for improvement of yield stability with crop management and breeding.

\section{Model description}

Figure 1 shows the simplified structure of the model. The calculation of crop growth under adequate soil water conditions is based on general crop growth simulators (Spitters et al., 1989; Penning de Vries et al., 1990). The development stage of the crop is simulated through integration of the rate of development, which is influenced

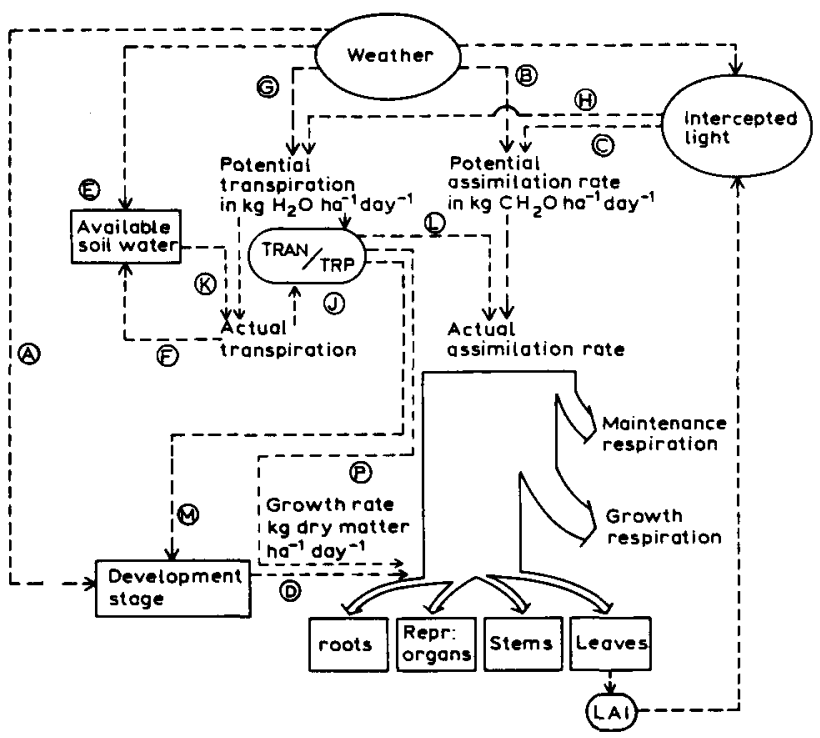

Fig. 1. Schematic representation of faba bean growth. NB: the scheme provides an overview, not a relation diagram. All the letters $(A, B, C \ldots$ to $P)$ at the dotted arrows correspond with explanations of the relations in the text. The arrows have to be interpreted as '...has effect on....' (in the direction of the arrow). For instance: TRAN/TRP has effect on photosynthesis (letter L), on development (letter $M)$, and on dry matter partitioning (letter $P$ ). 
by temperature (letter $\mathrm{A}$ in Figure 1). Assimilation rate is calculated from the incident amount of photosynthetically active radiation (PAR) (letter B in Figure 1), the fraction of PAR intercepted by the canopy (letter C in Figure 1), and the photosynthesis/light response curve of individual leaves. The total amount of carbohydrates available for growth is calculated from the assimilation rate, the reallocation and redistribution of dry matter on the one hand, and losses due to respiration of the plant organs ('maintenance respiration' in Figure 1) on the other. Dry matter growth of the plant organs is determined by the total net carbohydrate production, the fraction of carbohydrates allocated to the plant organs and the values for conversion of carbohydrates into dry matter ('growth respiration' in Figure 1). The fraction of carbohydrates allocated to the organs is affected by the development stage of the crop (cf. Van Heemst, 1986) (letter D in Figure 1). Leaf area growth is calculated from the dry matter allocated to the leaves and the specific leaf weight, which is also influenced by the development stage of the crop.

The parameters and functions specific for faba beans were mainly derived from experiments presented in Table 1a. The parameters for growth respiration were calculated from the chemical composition of plant organs, using equations of Vertregt \& Penning de Vries (1987). Table 2 presents some of the essential parameters and functions for faba beans*

Table 1. Experiments used for a) calibration and b) simulation studies

\begin{tabular}{|c|c|c|c|c|c|}
\hline Objective & Set & Sites & Years & Description & $\begin{array}{l}\text { Referen- } \\
\text { ce }^{* * *}\end{array}$ \\
\hline $\begin{array}{l}\text { a) Calibra- } \\
\text { tion }\end{array}$ & $\begin{array}{l}\text { silt } \\
\text { heavy clay } \\
\text { sand }\end{array}$ & $\begin{array}{l}\text { De Eest } \\
\text { De Bouwing } \\
\text { De Bouwing } \\
\text { De Bouwing } \\
\text { Droevendaal } \\
\text { Droevendaal } \\
\text { Droevendaal }\end{array}$ & $\begin{array}{l}1977 \\
1980 \\
1981 \\
1988 \\
1981 \\
1982 \\
1984\end{array}$ & $\begin{array}{l}\text { local growing conditions } \\
2 \text { irrigation treatments } \\
2 \text { irrigation treatments } \\
2 \text { irrigation treatments } \\
2 \text { irrigation treatments } \\
5 \text { irrigation treatments } \\
5 \text { irrigation treatments }\end{array}$ & $\begin{array}{l}\text { Gr1 } \\
\text { Gr1 } \\
\text { Gr1 } \\
\text { Gr1 } \\
\text { Gr1 } \\
\text { Gr1 }\end{array}$ \\
\hline $\begin{array}{l}\text { b) Simul- } \\
\text { ation } \\
\text { studies }\end{array}$ & $\begin{array}{l}1 \\
2 \\
3(\mathrm{JFBT})^{*} \\
4(\mathrm{MCB})^{* *}\end{array}$ & $\begin{array}{l}\text { De Bouwing } \\
\text { De Eest } \\
9 \text { locations, } \\
\text { W-Europe } \\
5 \text { Dutch lo- } \\
\text { cations }\end{array}$ & $\begin{array}{l}1975-1988 \\
1976-1989\end{array}$ & $\begin{array}{l}\text { local growing conditions } \\
\text { local growing conditions }\end{array}$ & Ebm \\
\hline
\end{tabular}

* JFBT-locations in Cambridge (UK), Dijon (F), Gottingen (G), Hohenheim (G), Dundee (UK), Roskilde (D), Nottingham (UK) and Vienna (A).

** MCB-locations Ebelsheerd, Lelystad, Valthermond, Vredepeel, Wijnandsrade.

*** Ebm: Ebmeyer (1984); Grl: Grashoff (1990a, 1990b); VdS: van der Schans \& van den Berg (1991). * A complete, documented listing of the simulation model and a quantification of all the parameters
and functions can be requested at the author's address. 


\section{WATER SUPPLY ON VICIA FABA L. 4.}

Table 2. Essential crop parameters and functions, specific for faba beans. Description in CSMPformat.

* Developmental rate in the vegetative and in the reproductive phase, respectively (d-1).

PARAM DVRV $=0.0268, \mathrm{DVRG}=0.0172$

* Effect of average daily temperature (deg. C) on developmental rate in the vegetative and * reproductive phase, respectively.

FUNCTION DVRVTT $=-10 ., 0.01,0 ., 0.01,20 ., 1 ., 30 ., 0.8$

FUNCTION DVRGTT $=0,0.01,4 ., 0.01,20 ., 1 ., 30 ., 1.2$

* Potential growth rate of roots into depth $(\mathrm{m} \mathrm{d}-1)$, Potential dying rate of roots into depth

* $\left(\mathrm{m} \mathrm{d}^{-1}\right)$, Maximum rooted depth $(\mathrm{m})$, Minimum rooted depth $(\mathrm{m})$.

PARAM PGRRT $=0.006$, PDRRT $=-0.006$, RTDMAX $=0.7$, RTDMIN $=0.5$

* Specific leaf weight (kg ha-1) in dependence on development stage.

FUNCTION SLWT = 0.,360., 0.6,320., 0.8,240., 1.,200., 1.2,320., 2.1,320.

* Maximum photosynthetic rate of single leaves (kg CO2 ha-1 d-1) and initial photosynthetic * efficiency ( $\mathrm{kg} \mathrm{CO} 2 \mathrm{ha}-1 \mathrm{~h}-1(\mathrm{~J} \mathrm{~m}-2 \mathrm{~s}-1)-1$ at reference temperatures of 15 and $10 \mathrm{deg} \mathrm{C}$, respectively.

PARAM PMAXP $=35 .$, PEI $=0.48$

* Extinction coefficient of the crop for diffuse radiation, scattering coefficient, and reflection

* coefficient of the leaves for total radiation.

PARAM KDIF $=0.7155, \mathrm{SCV}=0.2, \mathrm{RCLV}=0.1$

* Fraction of the crop growth rate allocated to the roots, shoots, leaves, stems, pod walls, seeds and

* reserves, in dependence on developmental stage.

FUNCTION CARTT $\quad=0 ., 0.5, \quad 1 ., 0.2, \quad 1.2,0 ., \quad 2.1,0$.

FUNCTION CASHT $=0 ., 0.5, \quad 1 ., 0.8, \quad 1.2,1 ., \quad 2.1,1$.

FUNCTION CALVT $\quad=0 ., 0.70, \quad 0.8,0.40, \quad 1 ., 0.30, \quad 1.2,0.10, \quad 1.3,0 ., \quad 1.6,0 ., \quad 2.1,0$.

FUNCTION CASTT $\quad=0 ., 0.25, \quad 0.8,0.50, \quad 1 ., 0.45, \quad 1.2,0.35, \quad 1.3,0.30, \quad 1.6,0 ., \quad 2.1,0$.

$\begin{array}{lllllll}\text { FUNCTION CAPWT }=0 ., 0 ., & 0.8,0 ., & 1 ., 0.10, & 1.2,0.30, & 1.3,0.30, & 1.6,0 ., & 2.1,0 .\end{array}$

FUNCTION CASET $\quad=0 ., 0 ., \quad 0.8,0 ., \quad 1 ., 0 ., \quad 1.2,0.25, \quad 1.3,0.40,1.6,1 ., \quad 2.1,1$.

FUNCTION CARET $\quad=0 ., 0.05, \quad 0.8,0.10, \quad 1.0 .15, \quad 1.2,0.00, \quad 1.3,0 ., \quad 1.6,0 ., \quad 2.1,0$.

* Conversion factor for $\mathrm{CH} 2 \mathrm{O}$ to dry matter for roots, leaves, stems, podwalls, seeds and reserves PARAM CFRT $=0.652, \mathrm{CFLV}=0.534, \mathrm{CFST}=0.693, \mathrm{CFPW}=0.687, \mathrm{CFSE}=0.608, \mathrm{CFRE}=0.790$

Detailed measurements of maintenance respiration were not available, so commonly used coefficients for the different plant organs were used (Spitters et al., 1989; Penning de Vries et al., 1990). For leaves and stems, the decrease of these coefficients with plant development was accounted for, using an approach described by Kropff (1989).

\section{Soil water balance}

A water balance model for a free draining soil profile is included, according to van Keulen $(1975 ; 1986)$ and Jansen \& Gosseye (1986). In this concept, the soil is divided in 10 layers of $10 \mathrm{~cm}$. The daily change in soil water content is calculated from rainfall (and irrigation) (letter $\mathrm{E}$ in Figure 1), crop transpiration (letter $\mathrm{F}$ in Figure 1), soil evaporation and percolation. Percolation is calculated as the amount of water in excess of field capacity, which drains to the next soil layer. Potential tran- 
spiration and evaporation are calculated with the combination equation of Penman. In this equation are included: the incoming radiation, air humidity and wind speed (all included in letter G in Figure 1), LAI and properties of the transpiring cq. evaporating surfaces (e.g. roughness, emissivity, reflectance, resistance for vapour transport) (generally represented by letter $\mathrm{H}$ in Figure 1). Soil evaporation is reduced when the upper layer of the soil dries out. The model does not calculate capillary rise, however the relative contribution of each soil layer to the total soil evaporation is calculated following a mimic procedure (van Keulen, 1975). In this concept, the relative contribution of each soil layer to the total evaporation decreases exponentially with the depth of the layer. The relative contribution of each soil layer to the total transpiration is based on the rooted length in each layer and the maximum water uptake per rooted length.

\section{Crop-water relations}

When the soil dries out, stomata close and transpiration falls below its potential value. The ratio between actual and potential transpiration (TRAN/TRP) (see at letter $\mathbf{J}$ in Figure 1), is supposed to decrease linearly with soil water content from unity at a critical water content, to zero at wilting point (Feddes et al., 1978) (letter K in Figure 1). The critical water content at which water uptake is reduced (which is somewhere below the field capacity of the soil) is not only dependent on the soil type. According to Doorenbos \& Kassam (1979) and Driessen (1986), the critical soil water content is also affected by the water extraction capacity of the crop and this differs between species. Based on the sensitivity of faba beans to water shortage, this crop belongs to the group with a rather 'weak' extracting capacity, like clover and carrots (Driessen, 1986). The critical soil water content is also affected (from day to day!) by TRP and

Table 3. Measured (meas) and simulated (simu) dates of onset of flowering (Julian date), seed yields ( $\mathrm{t} \mathrm{ha}^{-1} 100 \%$ dry matter), harvest indices $\left(\mathrm{g} \mathrm{g}^{-1}\right)$ and dates of crop maturity (Julian date) for different water supply treatments during and after flowering in 1980 and 1988 (clay soil) and 1982 (sandy soil). $\mathrm{d}=\mathrm{dry} ; \mathrm{i}=\mathrm{irrigated}$; $\mathrm{nr}=$ natural rainfall.

\begin{tabular}{|c|c|c|c|c|c|c|c|c|c|}
\hline \multirow[t]{2}{*}{ Year } & \multirow[t]{2}{*}{ Treatment } & \multicolumn{2}{|c|}{$\begin{array}{l}\text { Onset of } \\
\text { Flowering }\end{array}$} & \multicolumn{2}{|c|}{ Seed yield } & \multicolumn{2}{|c|}{ Harvest index } & \multicolumn{2}{|c|}{$\begin{array}{l}\text { Date of crop } \\
\text { maturity }\end{array}$} \\
\hline & & meas & simu & meas & simu & meas & simu & meas & simu \\
\hline 1980 & $\begin{array}{l}d-i \\
i-i\end{array}$ & $\begin{array}{l}152 \\
152\end{array}$ & $\begin{array}{l}152 \\
154\end{array}$ & $\begin{array}{l}6.3 \\
5.8\end{array}$ & $\begin{array}{l}6.3 \\
5.9\end{array}$ & $\begin{array}{l}0.62 \\
0.53\end{array}$ & $\begin{array}{l}0.52 \\
0.46\end{array}$ & $\begin{array}{l}259 \\
259\end{array}$ & $\begin{array}{l}251 \\
254\end{array}$ \\
\hline 1982 & $\begin{array}{l}\text { d-d } * \\
i-d \\
d-i \\
i-i \\
\text { nr. }\end{array}$ & $\begin{array}{l}150 \\
150 \\
150 \\
150 \\
150\end{array}$ & $\begin{array}{l}151 \\
151 \\
151 \\
151 \\
151\end{array}$ & $\begin{array}{l}4.0 \\
3.9 \\
6.2 \\
6.2 \\
4.1\end{array}$ & $\begin{array}{l}4.0 \\
3.6 \\
6.4 \\
6.0 \\
4.6\end{array}$ & $\begin{array}{l}0.60 \\
0.49 \\
0.64 \\
0.56 \\
0.57\end{array}$ & $\begin{array}{l}0.51 \\
0.38 \\
0.54 \\
0.49 \\
0.48\end{array}$ & $\begin{array}{l}231 \\
222 \\
237 \\
237 \\
222\end{array}$ & $\begin{array}{l}218 \\
220 \\
238 \\
241 \\
224\end{array}$ \\
\hline 1988 & $\begin{array}{l}d-i \\
i-i\end{array}$ & $\begin{array}{l}155 \\
155\end{array}$ & $\begin{array}{l}151 \\
151\end{array}$ & $\begin{array}{l}6.7 \\
6.0\end{array}$ & $\begin{array}{l}6.4 \\
6.2\end{array}$ & $\begin{array}{l}0.65 \\
0.56\end{array}$ & $\begin{array}{l}0.57 \\
0.51\end{array}$ & $\begin{array}{l}259 \\
266\end{array}$ & $\begin{array}{l}246 \\
249\end{array}$ \\
\hline
\end{tabular}

* In 1982, d-d got two irrigations after flowering (also included in the simulation). 
WATER SUPPLY ON VICIA FABA L. 4.
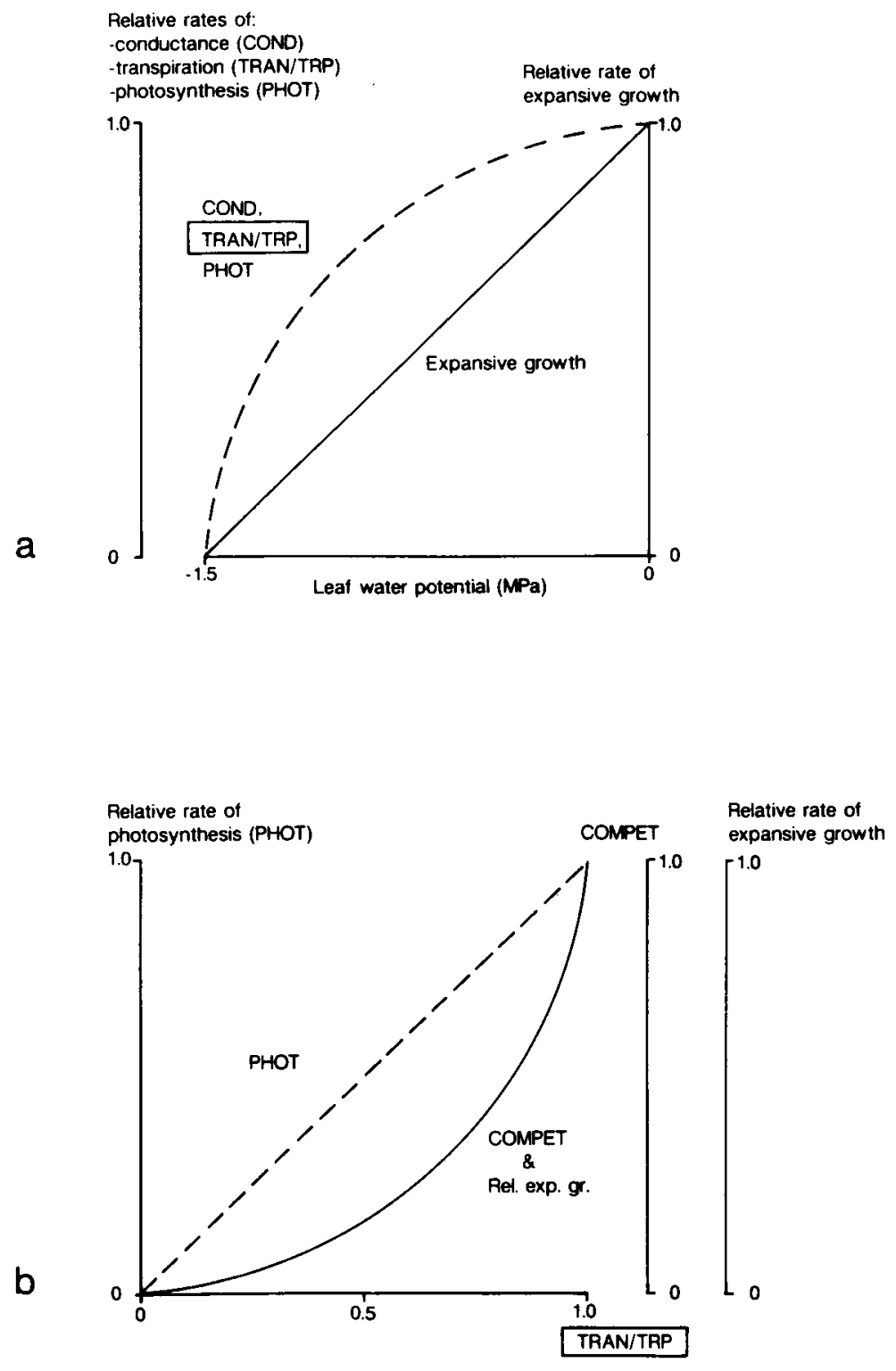

Fig. 2. a: The relations of relative conductance, transpiration (TRAN/TRP), photosynthesis and expansive growth rate versus leaf water potential (from Grashoff \& Verkerke 1991); b: The derived relations of vegetative growth, vegetative competition strength (COMPET) and photosynthesis versus TRAN/TRP. Rel. exp. gr. = relative rate of expansive growth. 
the leaf area index (LAI) (Jansen \& Gosseye, 1986). The ratio TRAN/TRP linearly affects the actual assimilation rate (letter $L$ in Figure 1), thus assuming a constant water use efficiency. The ratio TRAN/TRP indicates the level of the water availability to the crop.

Two other crop-water relations were included in the simulation model. Firstly, water shortage accelerates the development of the faba bean crop. With water shortage, pod development begins earlier in the season and maturity is reached earlier (Grashoff, 1990a; Table 3). In the model this process is accounted for by dividing the development rate (and the relative death rate) by the ratio TRAN/TRP, which represents the level of water availability to the crop. This relation is represented by letter $\mathbf{M}$ in Fig. 1. Our way of simulation implicitly assumes the following underlying mechanism: water shortage causes stomatal closure, lower transpiration rates, decreased 'cooling' of leaves, higher leaf temperatures and a higher development rate of the canopy (cf van Keulen \& Seligman, 1987). These arguments can only give a qualitative explanation. The quantification of our way of simulation was done by calibration based on experiments. This is shown in the section on model calibration of this article.

Secondly, faba beans show little osmotic adjustment under water shortage and, most probably by this reason, the expansive growth decreases linearly with decreasing leaf water potential (Grashoff \& Verkerke, 1991). The relative stomatal conductance, relative transpiration (TRAN/TRP) and relative assimilation decrease slower, following a negative exponential curve (Fig. 2a). Grashoff \& Verkerke (1991) stated that, with decreasing leaf water potential, these relations might result in a shift in competition for assimilates in favour of developing reproductive organs. In our simulation model however, calculation of leaf water potential is not included. When the leaf water potential in Fig. $2 \mathrm{a}$ is omitted, this results in an exponential curve for the relative expansive growth versus TRAN/TRP, and in a linear relation of relative assimilation versus TRAN/TRP (as shown in Fig. 2b). It is assumed that the expansive growth determines the sink strength of the vegetative shoot and consequently determines the fraction of assimilates flowing to the growing stems and leaves (Hsiao, 1976; Grashoff \& Verkerke, 1991). So, with decreasing TRAN/TRP, the fraction of assimilates flowing to the stems and leaves (COMPET) decreases much faster than the assimilation rate (Fig. 2b). The surplus assimilate is used for the developing pods and seeds. This effect is present from about onset of flowering till the end of allocation of assimilates to stems and leaves (about 6 weeks after end of flowering!). This relation is represented by letter $P$ in Figure 1 . The root growth is not affected by TRAN/TRP as we could not measure a clear effect of water shortage on root growth.

\section{Input data}

The input variables for the model are standard data of daily solar radiation, temperature, rainfall, air humidity and wind speed; date of crop emergence and values of crop dry matter and leaf area index at emergence; rootable depth; some characteristics of soil water retention, such as total pore space, volumetric soil water content at 
field capacity, at wilting point and at air-dry soil; reflection coefficient for total radiation of the soil, average clod height and extinction coefficient for soil evaporation.

\section{Model calibration}

Simulation of crop growth was calibrated on the basis of 7 field experiments with varying water supply patterns (Table 1a). This calibration is illustrated in Fig. 3. Figure 3a shows the measured dry matter production of cv. Minica grown on a heavy clay near Wageningen in 1988. Two irrigation treatments were included: 1) irrigated during and after flowering (henceforward referred to as $\mathbf{i - i}$ ) and 2) the natural rainfall. This rainfall pattern resulted in mild water shortage during flowering, followed by plenty of water afterwards ( $d-i)$. The d-i treatment showed the typical advanced start of seed growth, earlier maturity and higher final seed yields compared to $i-i$, as

a) De Bouwing 1988 Measured

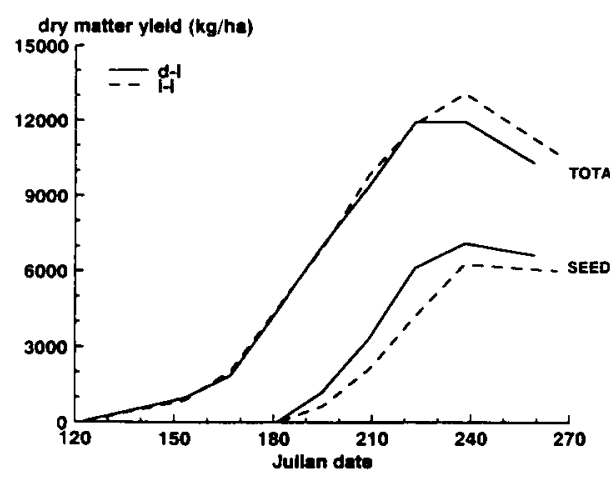

c) SImuiation 2

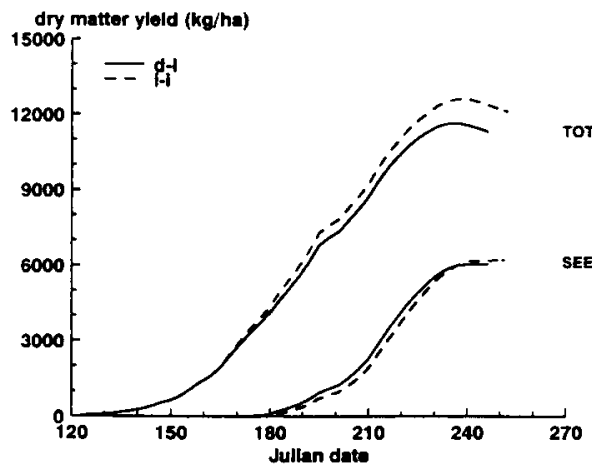

b) Simulation 1

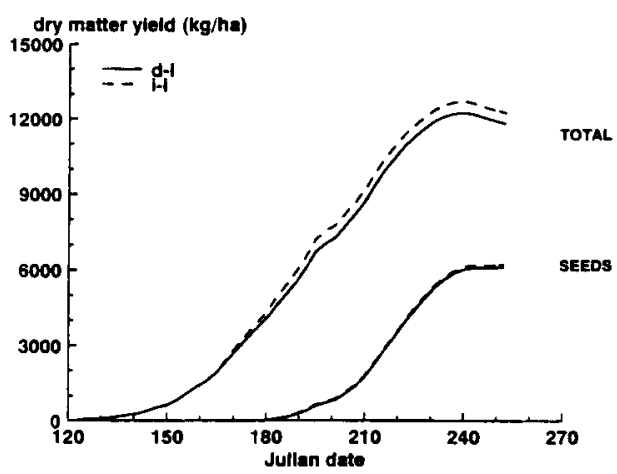

d) Simulation 3

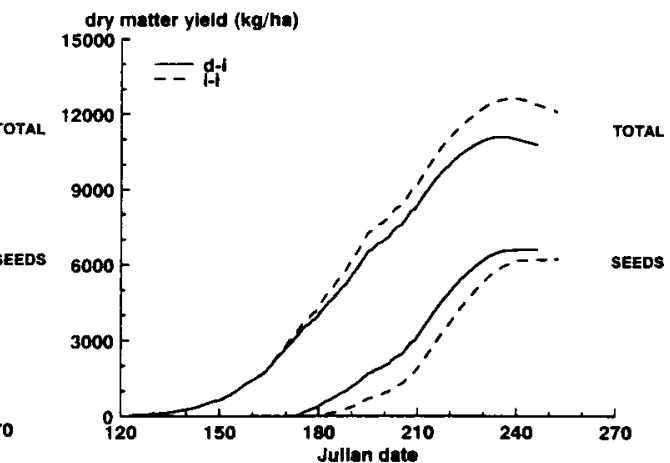

Fig. 3. Calibration of the simulation model. a: measured dry matter yields of two irrigation treatments $d-i$ and $i-i$, Wageningen, 1988; $b$ : simulation with water shortage only affecting assimilation rate ; $\mathrm{c}$ : as b but with added effect of water shortage on development rate (and relative death rates) of plant organs; d: as c but with added effect of water shortage on assimilate partitioning. 
described earlier by Grashoff (1990a) for similar experiments in 1980 and 1981 .

A simulation, including the relation of TRAN/TRP versus assimilation rate, but omitting the relations of TRAN/TRP versus development rate, and of TRAN/TRP versus dry matter partitioning, showed essential deviations from the experimental results: the advanced start of seed growth in d-i was not found in the simulation, and the simulated final seed yield of $i-i$ was higher than in $d-i$ (Fig. 3b). Figure $3 c$ shows the simulation result including the relations of TRAN/TRP versus (1) assimilation rate and (2) development rate. The simulated advanced start of seed growth in d-i agreed with the measured effect in Fig. 3a. Also the earlier maturity in $d-i$ than in $i-i$ is simulated more correctly. However, the simulated seed growth in $\mathrm{i}-\mathrm{i}$ caught up with $d-i$ and final seed yield in the $\mathrm{i}-\mathrm{i}$ simulation was higher than in $\mathrm{d}-\mathrm{i}$ (Fig. 3c). This essential contrast with the measurements remained in the simulation, even when (by trial and error) stronger accelerating effects of TRAN/TRP were explored with the model.

Figure $3 \mathrm{~d}$ shows the simulation result including the relations of TRAN/TRP versus (1) assimilation rate, (2) development rate and (3) assimilate partitioning, calibrated by 'trial and error'. This simulation shows the most correct agreement with the experimental results in Fig. 3a.

This calibration gave also good results for the other experiments of Table 1a. Some examples are shown in Table 3 . The model showed not only a good calculation of the positive effect of mild water shortage during flowering on seed yield and Harvest Index in 1980 and 1988, but also the growth and yield limitation due to water shortage after flowering in the experiments of 1982 was simulated correctly. However, the model showed some systematical over-estimation of the final Harvest Index, due to an over-estimation of straw weight in the last weeks before maturity. No attempt was made to simulate this feature correctly, because detailed measurements on respiration losses during maturation were not available.

\section{Data collection for studies on yield variability}

As input for the following simulation studies, data sets of crop performance, weather and soils were collected from four groups of locations in The Netherlands and Western Europe. Set 1: 14 years of experimental results on heavy clay in The Netherlands; set 2: results of 14 years on a silty loam soil with high capillary rise in The Netherlands; set 3: results of 2 years at 9 locations in Western Europe (subsequently called 'JFBT-trials'); set 4 ; results of 3 years on 5 regional experimental farms in The Netherlands ('MCB-trials'). An overview of the characteristics of all data sets is given in Table $1 b$.

To compare the simulations with experimental results, above-ground dry matter yield and seed yield at final harvest were used. In the MCB-trials, 3 different sowing times were used, classified as 'early' (beginning of April), 'middle' (end of April) and 'late' (end of May). Disease attack was classified as 'absent or mild', 'moderate' or 'severe', based on observations in the canopy. 'Absent or mild' was defined as: no occurrence of disease symptoms, or only late in senescence; 'moderate' was: clear occurrence of leaf damage during pod filling; 'severe' was: damage of canopy early 
in the season, and damage of pods and seed loss at final stages (van der Schans \& van den Berg, 1991). The observed diseases were mainly leaf-spot diseases (Botrytis, Uromyces) and virus diseases (especially the Bean Leaf Roll Virus, BLRV). The above classifications were used for further analysis of residual deviations between simulated and measured yields.

\section{Results of the studies on yield variability}

Yield variability on De Bouwing 1975-1988 (data set 1)

The data set of the De Bouwing Experimental Farm (set 1 in Table 1b) shows a good agreement between measured and simulated average seed yields (measured 5.3 and simulated $5.3 \mathrm{t} \mathrm{ha}^{-1}$ ) (Fig. 4a). The yield variability, expressed as the standard deviation, was $1.3 \mathrm{t} \mathrm{ha}^{-1}$ for the measured data set and $1.5 \mathrm{t} \mathrm{ha}^{-1}$ for the simulated set. This set is subsequently referred to as the 'control' simulation. For 1979, the model
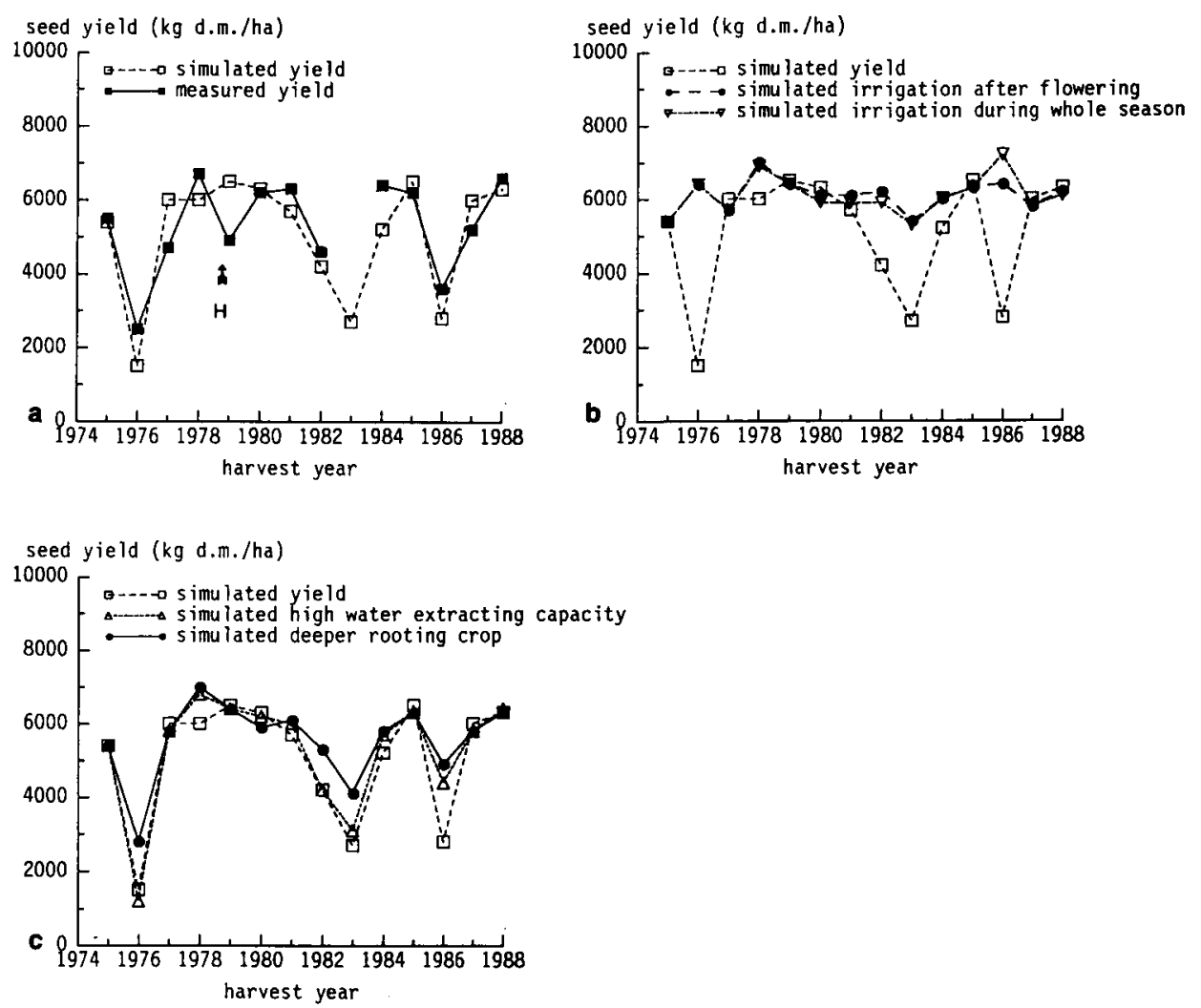

Fig. 4. Simulation studies with the data set of De Bouwing 1975-1989 (data set 1).

a: comparison between measured and simulated yields; b: model explorations with irrigation; $c$ : model explorations with breeding strategies. $\mathrm{H}=$ hail and frost damage in 1979. 
showed a large over-estimation of the seed yield. A possible explanation is the fact that the 1979 crop was severely damaged by frost in spring and by hail. These effects are not included in the model, as quantified relations between hail or frost and crop damage are not available for faba beans. A linear regression of simulated versus measured yields, fitted through the origin, had a slope of 0.99 and accounted for $68 \%$ of the variation. When the data pair of 1979 was excluded from analysis, this percentage increased to $77 \%$.

Simulation of a situation with plenty of water after the end of flowering resulted in stabilization of yield (standard deviation was $0.4 \mathrm{t} \mathrm{ha}^{-1}$ compared with $1.5 \mathrm{t} \mathrm{ha}^{-1}$ for the 'control' simulation) on a high level of seed production (average of $6.2 \mathrm{t} \mathrm{ha}^{-1}$ ) (Fig. 4b). Plenty of water during whole season was slightly less advantageous, with an average seed yield of $6.1 \mathrm{t} \mathrm{ha}^{-1}$ and a standard deviation of $0.5 \mathrm{t} \mathrm{ha}^{-1}$. Only in 1986 , plenty of water during the whole season gave a higher seed yield than plenty of water after flowering. This exception will be discussed later. In the model, plenty of water was realized by surplus irrigations of $20 \mathrm{~mm} \mathrm{~d}^{-1}$. This results simply in a soil at field capacity. Surplus water drains off (in the model) and has no negative effect on growth.

In a second simulation study the effect of a deeper rooting crop was explored. The standard values for root growth rate $\left(0.006 \mathrm{~m} \mathrm{~d}^{-1}\right)$ and maximum rooted depth $(0.7 \mathrm{~m})$ were doubled to $0.012 \mathrm{~m} \mathrm{~d}^{-1}$ and $1.4 \mathrm{~m}$ respectively. This corresponds to a larger available and exploitable water buffer. Compared to the 'control' simulation, this resulted in an increase of average seed yield to $5.7 \mathrm{t} \mathrm{ha}^{-1}$ and a reduction of variability (standard deviation $\left.=1.0 \mathrm{t} \mathrm{ha}^{-1}\right)(\mathrm{Fig}$. $4 \mathrm{c})$. Increasing only the root growth rate or only the maximum rooted depth showed almost no effect compared to the 'control' simulation.

In a third study, the root growth rate and the rooting depth were kept at their original values, but now it was assumed that a faba bean crop could be 'bred' with a soil water extraction capacity comparable to sorghum and sugar cane (Driessen, 1986). In the model, this is expressed as a change of the water uptake characteristics of the crop. It means a doubling of the average soil water content range between field capacity and the critical soil water content below which actual crop transpiration is reduced. Compared to the 'control' simulation, the average seed yield increased only to $5.4 \mathrm{t} \mathrm{ha}^{-1}$ and the standard deviation remained $1.5 \mathrm{t} \mathrm{ha}^{-1}$ (Fig. $4 \mathrm{c}$ ).

\section{Yield variability on De Eest 1976-1989 (data set 2)}

In contrast with the results for De Bouwing, the data set of De Eest (set 2 in Table 1b) showed little agreement between measured and simulated seed yields (Fig. 5). The measured average seed yield $\left(6.4 \mathrm{t} \mathrm{ha}^{-1}\right)$ was underestimated by the simulation $\left(5.6 \mathrm{t} \mathrm{ha}^{-1}\right)$ and the measured variability (standard deviation $1.0 \mathrm{t} \mathrm{ha}^{-1}$ ) was overestimated $\left(1.4 \mathrm{t} \mathrm{ha}^{-1}\right)$. Moreover, a linear regression fitted through the origin accounted for less than $1 \%$ of the variation. A regression not fitted through the origin accounted for only $10 \%$ of the variation. No data pair could be excluded from analysis for specific reasons.

The soil of De Eest can provide the crop with important amounts of capillary 
seed yield (kg/ha)

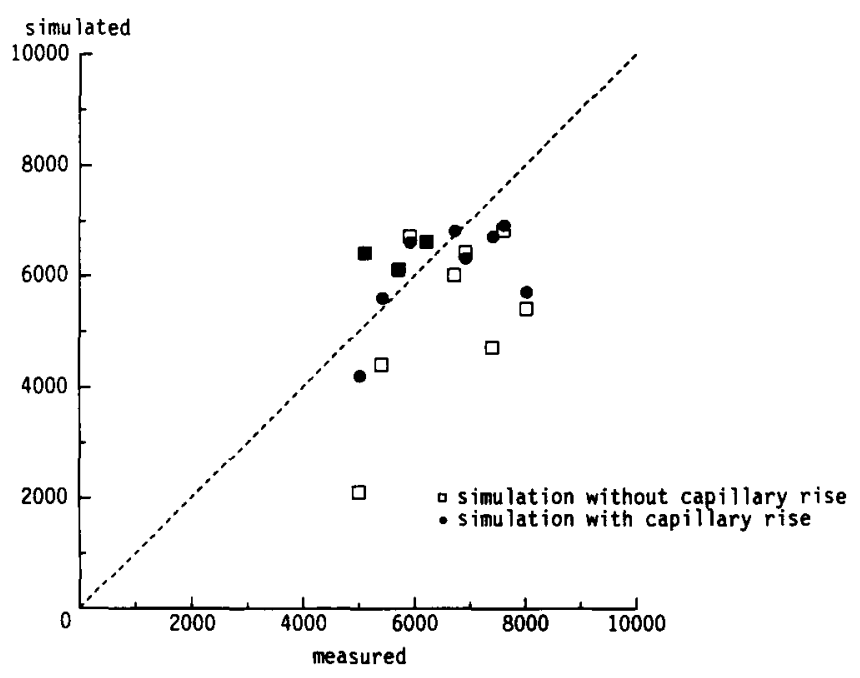

Fig. 5. Measured versus simulated seed yields of the data set of De Eest 19761989 (data set 2). Open squares: standard simulation; closed circles: explorative simulation with "capillary rise' with a maximum of $5 \mathrm{~mm} \mathrm{~d}^{-1}$.

rising ground water. A capillary supply of $2 \mathrm{~mm} \mathrm{~d}^{-1}$ is possible at a distance of $1.3 \mathrm{~m}$ between the ground water level and the bottom of the rooted zone (this is called the 'Z-value'). The ground water level at De Eest is about $-1.2 \mathrm{~m}$ from the soil surface in normal years and never falls below $-2 \mathrm{~m}$, not even in extremely dry years (J.Sinke, personal communication).

The process of capillary rise is not included in the model, but the effect of capillary rise was explored in a rough and simple way. It was assumed that a negative linear relation exists between the averaged soil water content of the upper $70 \mathrm{~cm}$ of the soil profile and the additional water supply by capillary rise from deeper soil layers. The maximum capillary water supply was assumed to be reached at the permanent wilting point. To avoid complex adaptations of the model, the additional water was supplied at the top layer of the soil. For each year at De Eest, five simulation runs were carried out with amounts of maximum 'capillary water supply' of respectively $0,5,7.5,10$ and $15 \mathrm{~mm} \mathrm{~d}^{-1}$. The largest improvement of correlation between measured and simulated seed yields was reached with a maximum capillary rise of $5 \mathrm{~mm} \mathrm{~d}^{-1}$, and these results were included in Fig. 5. The simulated average seed yield increased from $5.6 \mathrm{t} \mathrm{ha}^{-1}$ to $6.2 \mathrm{t} \mathrm{ha}^{-1}$ (measured: $6.4 \mathrm{t} \mathrm{ha}^{-1}$ ) and the standard deviation decreased from $1.4 \mathrm{t} \mathrm{ha}^{-1}$ to $0.8 \mathrm{t} \mathrm{ha}^{-1}$ (measured $1.0 \mathrm{t} \mathrm{ha}^{-1}$ ). The percentage of variation accounted for increased from $10 \%$ to $21 \%$.

Yield variability in JFBT-trials 1985 and 1986 (data set 3)

Analysis of the data from the 9 West-European JFBT-locations (set 3 in Table $1 b$ ) showed that a linear regression of simulated versus measured seed yields, fitted through the origin, accounted for only $12 \%$ of the variation. Figure 6 shows that for 
seed yleld (kg/ha)

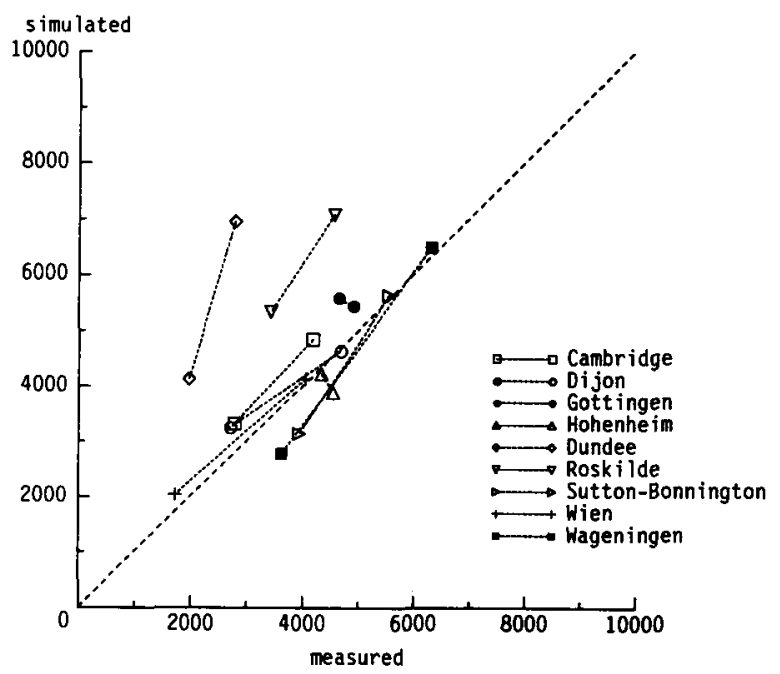

Fig. 6. Measured versus simulated seed yields of the data set of 9 locations in Western Europe 1985 and 1986 (data set 3).

6 out of 8 locations, simulated values showed almost a one-to-one relation with the measured values of 1985 and 1986. Yields were strongly overestimated for the locations at Dundee and Roskilde. It is not likely that these deviations are due to effects of low temperatures at these northern locations. The effects of temperature (on development rate, photosynthesis and respiration) are included in the model. Dundee 1985 and 1986 and Roskilde 1985 showed high average values for lodging ( 5 on a scale of $1=$ no lodging, to $9=$ severe) and damage by Botrytis fabae was observed. These effects are not included in the model, as quantified relations between lodging or diseases and crop damage are not available for faba beans. When these locations were excluded from analysis, a linear regression fitted through the origin showed a slope of 1.0 and accounted for $81 \%$ of the variation.

The average of the simulated seed yields over all locations and both years $(4.5 \mathrm{t}$ $\left.\mathrm{ha}^{-1}\right)$ was higher than the measured value $\left(3.9 \mathrm{t} \mathrm{ha}^{-1}\right)$. The simulated variability was only slightly overestimated, with a standard deviation of $1.4 \mathrm{t} \mathrm{ha}^{-1}$ for the simulated yields and a standard deviation of 1.2 for the measured yields. The relative standard deviation for simulated and measured yields was equal $(30 \%)$.

In an exploration with plenty of water after the end of flowering, the model simulated a large reduction in variability of seed yield (standard deviation $=0.8 \mathrm{t}$ $\left.\mathrm{ha}^{-1}\right)$ and a higher average seed yield $\left(6.4 \mathrm{t} \mathrm{ha}^{-1}\right)$. This was mainly due to the fact that the irrigations enhanced the low yields of 1986 (compare the 1986 data in the Figs 7 a and $7 \mathrm{~b}$ ). Actually, the growing season of 1986 had less rainfall and higher temperatures than 1985 at most locations. Averaged over the locations, the precipitation rate of June and July was $150 \mathrm{~mm}$ in 1985 and $90 \mathrm{~mm}$ in 1986. An exploration with plenty of water during the whole season resulted also in an average seed yield of 6.4 $\mathrm{t} \mathrm{ha}^{-1}$ and a standard deviation of $0.8 \mathrm{t} \mathrm{ha}^{-1}$ (Fig. 7c). At some locations, seed yields 

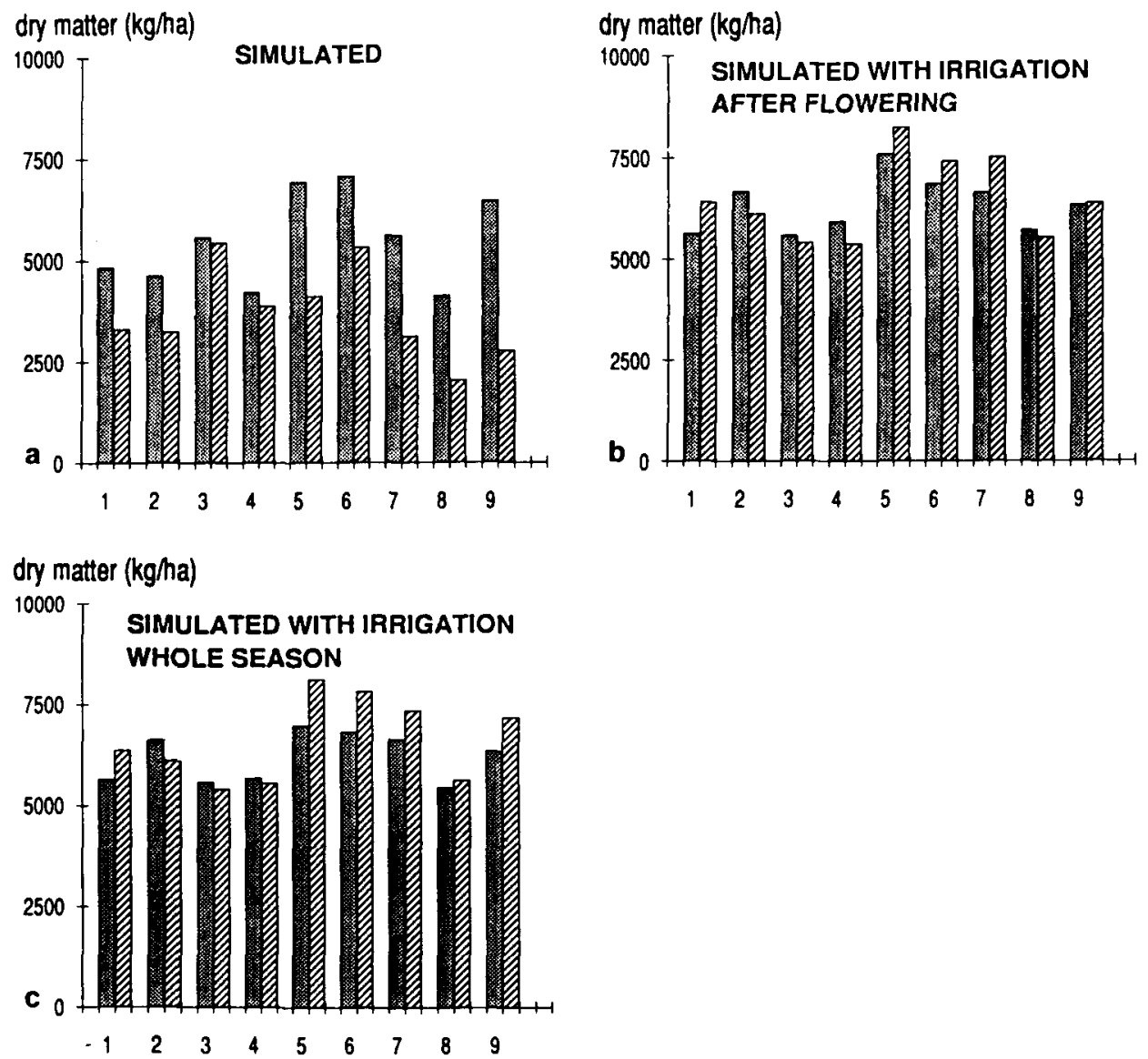

Fig. 7. Simulation studies with the JFBT data set of 9 locations in Western Europe, 1985 and 1986 (data set 3). a: simulated yields; $b$ and $c$ : model explorations with irrigation. $1=$ Cambridge. $2=$ Dijon. $3=$ Gottingen. $4=$ Hohenheim. $5=$ Dundee. $6=$ Roskilde. $7=$ Nottingham. $8=$ Vienna. $9=$ Wageningen .

with plenty of water after flowering were slightly higher than with plenty of water during the whole growing season (compare Figs $7 \mathrm{~b}$ and 7c: especially Dundee 1985, but also Hohenheim 1985 and Vienna 1985). But, for some other locations the reverse effect was simulated (Figures $7 \mathrm{~b}$ and $7 \mathrm{c}$ : Roskilde 1986, Wageningen 1986). It is concluded that plenty of water after flowering is almost as effective for yield stabilization as plenty of water during the whole season, but does not always give the optimum seed yields.

Exploration of optimum soil water content for seed production of faba beans

Next, the required soil water contents in different development stages for optimum 


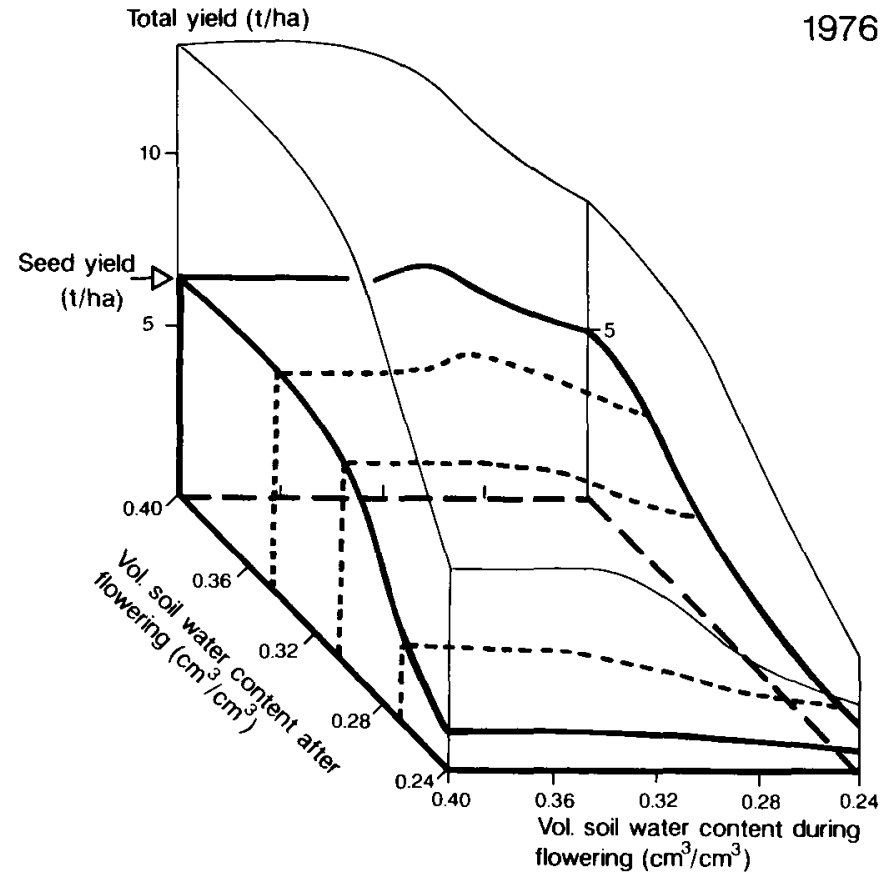

Fig. 8. Simulation studies with various 'fixed' soil water contents during flowering and after flowering. Climatic and soil data for De Bouwing, 1976. Vol. $=$ volumetric.

seed yield were explored. Fixed values for soil water content were used as input 'forcing functions' for the model and simulation runs were made, varying these values in the development periods 'during flowering' and 'after flowering'. The soil water content 'before flowering' was kept at field capacity in all runs and was allowed to change immediately after the start of the next development period. The first results showed that the best stages for changing soil water contents for optimum seed production, were not exactly the beginning and end of flowering, but the start of the first pod development (about one week after onset of flowering) and the point at which the assimilate partitioning to reproductive organs exceeds the flow to stems and leaves (about two weeks after end of flowering). In subsequent runs, these stages were used.

Figure 8 shows the results for the clay soil of experimental farm De Bouwing, with a volumetric soil water content of $0.40 \mathrm{~cm}^{3} \mathrm{~cm}^{-3}$ at field capacity and of 0.22 at permanent wilting point. In this example, the climatic data of 1976 were used. The total dry matter yield increased with increasing soil water content until a level at 0.32 $\mathrm{cm}^{3} \mathrm{~cm}^{-3}$ either during or after flowering. However, the curve of simulated final seed yields showed an optimum at an average soil water content during flowering of 0.30 $\mathrm{cm}^{3} \mathrm{~cm}^{-3}$. The simulated seed yields increased with increasing average soil water content after flowering.

When other years were simulated, the general shape of the resulting curves was the same as in Fig. 8. However, the optimum soil water content during flowering was different for each of the years (1976-1988) and varied between 0.27 and $0.32 \mathrm{~cm}^{3}$ 
WATER SUPPLY ON VICIA FABA L. 4.

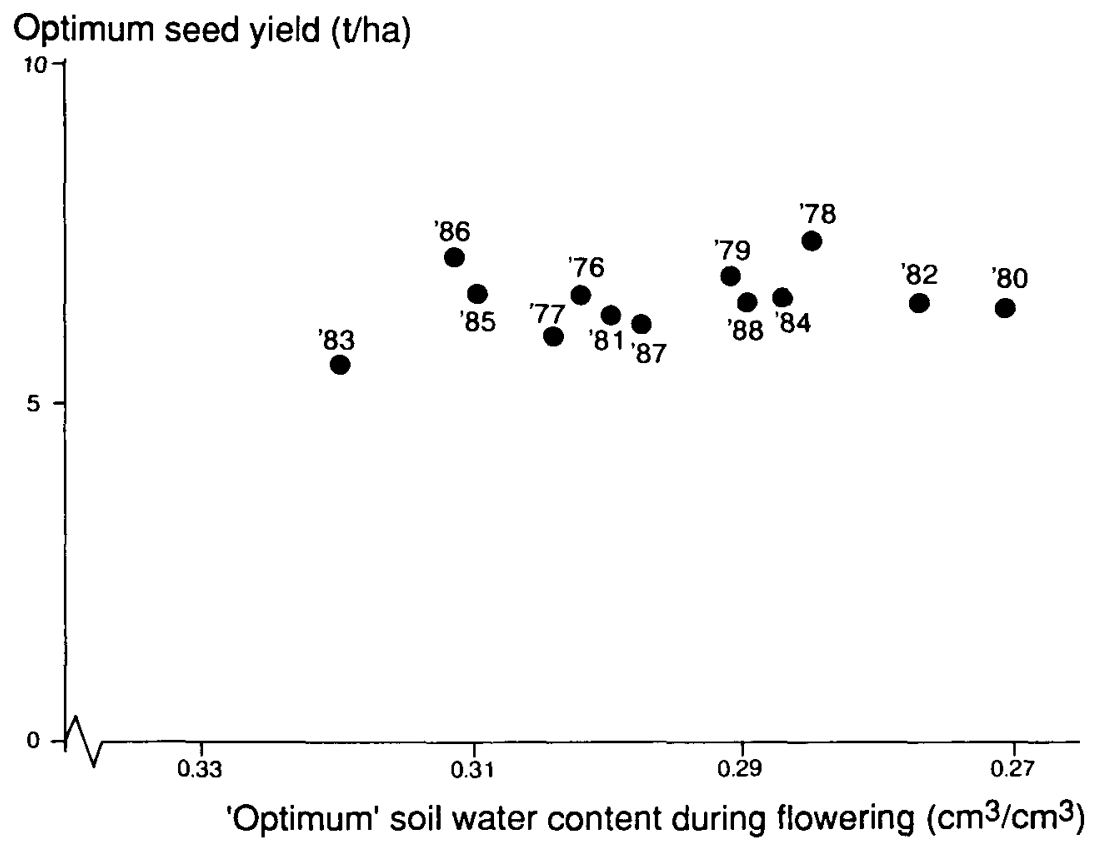

Fig. 9. Simulated soil water contents during flowering, required for optimum final seed yields for De Bouwing 1976-1988 (data set 1). The water content after flowering was kept at field capacity in all years.

$\mathrm{cm}^{-3}$ for this soil type (Fig. 9). Seed yield reductions up to $500 \mathrm{~kg} \mathrm{ha}^{-1}$ were found with super-optimum water contents during flowering. Sub-optimum water contents during flowering resulted in larger yield reductions. In all the years, final seed yields increased with increasing average soil water contents after flowering, but showed no further increase with soil water contents higher than $0.32 \mathrm{~cm}^{3} \mathrm{~cm}^{-3}$. Simulation results with other locations and soil types were comparable with those presented in the Figs 8 and 9.

\section{Yield variability in the MCB-trials 1987-1989 (data set 4)}

Finally, the data from the 5 regional farms in the Netherlands (set 4 in Table 1b) were analysed with the model. In contrast with the other trials, which were kept as healthy as possible, these 'MCB-trials' were practice-oriented (including treatments with different sowing times), with disease protection as commonly advised for practice. The growing seasons of 1987 and 1988 were 'wet', with more precipitation than normal in June and July (1987) or July and August (1988). The season of 1989 was warmer than normal, but periods of extreme water shortage did not occur (van der Schans \& van den Berg, 1991). When all the results of the MCB-experiments were plotted as one group, a linear regression between measured and simulated results 


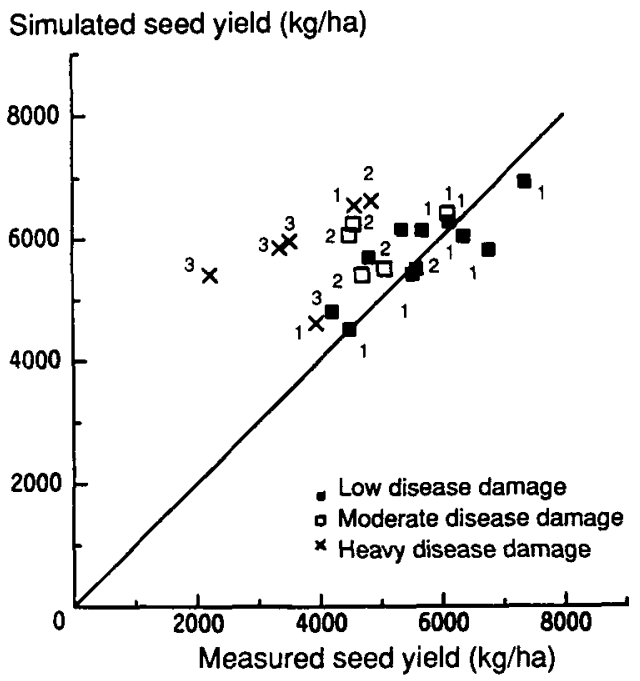

Fig. 10. Simulation studies with the MCB data set of five regional experimental farms in 1987-1989 (data set 4). The data are classified in three groups of disease attack. The small numbers refer to the different sowing times (1='early'; 2='middle'; 3='late').

could not be fitted through the origin. Even a regression line not fitted through the origin accounted for only $19 \%$ of the variation and showed a large deviation from a one-to-one relation. From field observations it appeared that diseases might have had important effects in these trials. Disease damage is not included in the model, as relations between diseases and crop damage are not yet quantified for faba beans. However, the measured yields (with possible disease damage) could be compared with simulated yields (without the effect of diseases). For this comparison, the results were classified according to the field observations about disease attack of the foliage. Now it appeared that measured and simulated yields in the group with 'absent or mild' disease attack agreed well, with only small deviations from the diagonal, up to about $1 \mathrm{t} \mathrm{ha}^{-1}$ (Fig. 10). In this group, a linear regression accounted for $32 \%$ of the variation (when it was fitted through the origin) or for $67 \%$ (when it was not fitted through the origin). In the group with 'moderate' disease attack, the deviations increased to $2 \mathrm{t} \mathrm{ha}^{-1}$ and with 'heavy' disease attack even to $3.5 \mathrm{t} \mathrm{ha}^{-1}$. Figure 10 shows also, that the group with 'absent or mild' disease attack consisted mostly of data from crops which were sown 'early', at the beginning of April. The largest deviations in the group with 'heavy' disease attack were data from crops which were sown 'late', at the end of May. However, also some crops sown at the beginning or at the end of April belonged to the group with 'heavy' disease attack (Fig. 10).

\section{Discussion}

The regressions of simulated versus measured seed yields (excluding some disturbances due to hail or lodging) accounted for almost $80 \%$ of the variation of the data sets of De Bouwing (data set 1) and the West-European JFBT-locations (data set 3). This means that a large part of the observed yield variability is caused by variability of the input values in the model: radiation, temperature, air humidity, wind speed, 
rainfall and soil characteristics. Our results show that a large yield variation range is caused by the variation of these input data: for the West-European JFBT locations, the yield variation range due to the factors included in the model was $4.5 \mathrm{tha}^{-1}$. (This is calculated from the difference between the lowest and the highest yield data on, or close to the diagonal in Figure 6.) These results were based on data sets of 9 locations, but only for 2 contrasting years, as weather data sets of many years were not available. The weather data set of 14 years for De Bouwing can be seen as an example for the variability in longer term data, but only for one location. Anyhow, as the yield variation range of the JFBT-locations was almost as large as that of De Bouwing (Figure 4), this indicates that those two data sets covered at least an important part of possible variation in weather and yields in Western Europe.

In the simulation studies, irrigation increased the average yield by $15 \%$ for De Bouwing and $40 \%$ for the West-European JFBT locations and reduced the yield variability by $75 \%$ and $60 \%$, respectively. That means that water supply is the major factor affecting yield variability. Irrigation stabilized the seed yields at an average level of about $6 \mathrm{t} \mathrm{ha}^{-1}$, due to yield increments in dry years, not only for one location (Fig. 4, De Bouwing), but for many locations in Western Europe (Fig. 7). The simulation studies support that variability in rate and distribution of water supply between years is a major cause of variability in yield of faba beans grown in Western Europe.

The model does not account for effects of capillary rising ground water. The simulations accounted for less than $10 \%$ of the variation and underestimated the average seed yield with $0.8 \mathrm{t} \mathrm{ha}^{-1}$ for the location De Eest (data set 3; Fig. 5), where capillary rise is likely to be important, due to soil type and ground water table. Our model was able to support the importance of capillary rise, using explorations with additional 'capillary water supply'. These showed an improved agreement between measured and simulated values of average seed yields and yield variability (Fig. 5). The percentage of accounted variation increased to $20 \%$. However, this value is still very low and a regression fitted through the origin was not possible. This low value was mainly due to a measured top seed yield of $8 \mathrm{t} \mathrm{ha}^{-1}$ in 1982 , which was not reached in any of the simulations for 1982. If this value was excluded, the percentage of accounted variation increased to $61 \%$ (regression not fitted through the origin) or $24 \%$ (fitted through the origin). Our method simulating 'capillary rise' was rough, as it was not based on independently quantified processes. Moreover, it was not realistic, as we added the additional water to the top layer of the soil, to avoid complex adaptations of the model. Models which simulate capillary rise in a physical proper way are available (Penning de Vries et al., 1990). However, the calibration of such models can be a bottle-neck, although improvements have been made (Woodhead et al., 1991).

At the other hand, it can be questioned if a model including capillary rise is needed for simulations in Western Europe. De Eest has a 'Z-value' (see before) for $2 \mathrm{~mm}$ capillary water supply per day of $1.3 \mathrm{~m}$, with a ground water table of $-1.2 \mathrm{~m}$. Locations, with such a high capillary rise, combined with an almost optimum and constant ground water table, are scarce in Western Europe. For instance, the Z-value for De Bouwing is only $40 \mathrm{~cm}$. 
The presented results show that crop management methods and breeding strategies which reduce or avoid water shortage are very important. The simplest solution would be to grow faba beans on soils with high capillary rise, such as De Eest. In fact, this location was the highest-yielding location in almost all the JFBT trials from 1977 onwards (cf. Dantuma et al., 1983; Ebmeyer, 1984). However, as these soils are scarce, this solution is not very realistic.

Optimization of irrigation strategy is a second possibility. As simulation studies for De Bouwing did not differ essentially from our studies with other soil types without capillary rise, the results of De Bouwing will be discussed as an example. Figure 8 shows that, after flowering, the soil water content in the clay at De Bouwing has to be higher than $0.32 \mathrm{~cm}^{3} \mathrm{~cm}^{-3}$ for both maximum seed yield and maximum total yield. Seed yield decreases linearly with lower soil water contents after flowering. During flowering, however, the required soil water content for optimum final seed yield is lower than for maximum total yield. For De Bouwing 1976, the simulated optimum value during flowering was $0.30 \mathrm{~cm}^{3} \mathrm{~cm}^{-3}$. Comparable simulations for 1975-1988 showed, that super-optimum water contents during flowering can reduce final seed yields with up to $500 \mathrm{~kg} \mathrm{ha}^{-1}$.

However, sub-optimum water contents during flowering can result in larger seed yield reductions than super-optimum contents (Fig. 8). In fact, this figure shows that, when the soil water content during flowering becomes much lower than the required optimum, onset of irrigation after flowering is too late. This might explain why in some exceptions, such as Wageningen 1986 (Fig. 4) and Roskilde 1986 (Fig. 7), the seed yields with plenty of water during the whole season were higher than with plenty of water after flowering. The spring of 1986 was in fact very dry. So, although postponement of irrigation till after flowering has a positive effect on dry matter distribution to the seeds (Fig. 2, Table 3), it does not always give higher final seed yields than irrigation during the whole growing season.

From the previous sections it is concluded that, in general, the explorative simulation studies (Figs 4, 6, 7 and 8) support the conclusions from experimental work (Grashoff, 1990a, 1990b), that irrigation, applied mainly after flowering, can be as effective for yield stabilization as irrigation during the whole season. Defining and maintaining the 'optimum level of mild water shortage during flowering' needs further attention. The simulations indicate that these conclusions can be generalized to other weather conditions, soils and sites.

Grashoff (1990b) stated that simulation studies might help to define the critical soil water values for optimizing water supply. Figure 8 shows that the model can quantify the soil water content representing an 'optimum level of mild water shortage during flowering' (Grashoff, 1990a) . Figure 8, however, holds only for a single year. Figure 9 shows that this optimum itself is not constant. For the location De Bouwing, it varies between 0.27 and $0.32 \mathrm{~cm}^{3} \mathrm{~cm}^{-3}$ for different years, corresponding to $\mathrm{pF}$ values of 3 and 2.3, respectively. This is caused by the fact that daily temperature, air humidity and windspeed, which differ for the flowering period in each year, affect the daily potential transpiration TRP. In our model concept, this modifies the critical soil water content at which TRAN/TRP starts to decrease. Consequently, also the soil water content for optimum dry matter partitioning during flowering differs for each 
day and year and a 'general' optimum value cannot be defined. Nevertheless, the Figs 8 and 9 indicate, that a 'preferred' range of soil water contents during flowering can be defined which do not always give optimum yields, but stabilize yields on an acceptable level. For the soil of De Bouwing, the soil water content during flowering should be kept up or above the average value for optimum seed yields $\left(0.30 \mathrm{~cm}^{3}\right.$ $\mathrm{cm}^{-3}$ ). After flowering, water content should not be lower than is required for maximum total yie!ds (for De Bouwing $0.32 \mathrm{~cm}^{3} \mathrm{~cm}^{-3}$ in all years). It appears that the simulated 'target' soil water content during flowering is only slightly lower than the simulated 'target' water content after flowering. Obviously, under very dry weather conditions irrigation is not only needed after flowering, but even during flowering.

A third possibility to optimize faba bean yields was shown in the evaluation of some breeding strategies for ideotypes. A doubling of the rooted soil depth, combined with a doubling of the root growth rate, decreased the variability by $35 \%$. That indicates that this breeding strategy is less effective for yield stabilization than irrigation activities are. Nevertheless, from an economical or practical point of view, breeding for deeper rooting varieties has some advantages, as irrigations are expensive or even simply not possible in some situations. Breeding for deeper rooting varieties may be more effective than breeding for a faba bean with 'sorghum-like' water extraction capability, which had no effect on yield variability at all (Fig. 4c). With a higher extraction capacity, the model calculates a higher growth rate in the early growing season of a dry year. But, at continuing water shortage, the soil water buffer is exhausted by the crop before the seed production is completed. That explains why the final seed yield can be even lower with higher extraction capacity (Fig. 4c, 1976). In our simulations was not accounted for extra carbohydrate investments in a higher rooting density to obtain a higher water extraction capacity. Van Keulen et al. (1975) showed that rooting density is not likely to be the major limiting factor for the water extraction capacity.

The previously discussed management activities and breeding strategies dealt with water shortage. In our model, the nitrogen balance of the crop and processes concerning nitrogen fixation are not included. Nevertheless, the simulated yields agreed well with the measured yields, for many years and weather conditions (Fig. 4) and at many locations (Fig. 6). This indicates, that in a simulation model for a leguminous crop, the inclusion of, for instance, effects of water shortage on nitrogen fixation (Roughly et al., 1983; Shamsun Noor et al., 1989) are not needed, at least not explicitly.

However, other important factors were found. In the regressions shown before, some data pairs were excluded from analysis (Fig. 4a, 1979; Fig. 6, Roskilde, Dundee). These data pairs deviated due to effects not accounted for in the model, like hail damage, lodging and diseases. These were interpreted as accidental disturbances and therefore excluded. The analysis of the MCB-data (set 4) clearly shows that this is an oversimplification of the situation in practice. The simulation model did not account for any substantial part of the variation in the total MCB-data set of five experimental farms in The Netherlands.

Nevertheless, Figure 10 shows that the deviation of measured and simulated yield pairs from the diagonal increased from $1 \mathrm{t} \mathrm{ha}^{-1}$ for the group of 'absent or low' 
disease attack to $3.5 \mathrm{t} \mathrm{ha}^{-1}$ in the 'severe' group. This shows that the model also helps to discover or estimate yield reductions due to factors not accounted for in the model. Apparently, in the MCB-data set, diseases were more important for yield variability than water shortage. An important question is why diseases were more important than in the previous data sets. A tendency was found that disease damage increased with later sowing times in the MCB-trials (Fig. 10). Fungi disease pressure usually increases with humid conditions in the season and these conditions occurred especially during July in both 1987 and 1988. At a certain calendar date the late sown crops are usually in an earlier development stage as the early sown crops. In this way, diseases may be more harmful in the late sown crops, as they may cause damage during a longer development period. However, there was disease protection in the MCB-trials, but this was obviously not effective enough. This is somewhat in contrast with opinions in the Netherlands Extension Service some years ago, that it was possible to control the most common diseases and pests in faba beans (chocolate-spot, rust, aphids) in an effective way. A first reason for this contrast might be, that the attack of the Bean Leaf Roll Virus (BLRV) during 1987-1989 was more important than in previous years, due to warm winters and early increase of aphid populations. Secondly, crop protection might have been more intense and preventive in trials at De Bouwing and in the JFBT, than in the practice oriented MCB-trials.

The general conclusion is that water shortage is in many cases the major limiting factor for yield in Western Europe and causes considerable yield variation. However, crop growth reducing factors such as diseases may sometimes overrule these effects (Fig. 10). The present simulation study has shown how control of water availability could stabilize faba bean yields within an acceptable range in many environments. In addition, the simulations indicate that disease control is then becoming even more essential.

\section{Acknowledgements}

The authors wish to express their thanks to Dr S.C. van de Geijn (CABO-DLO) and Prof. Dr Ir R. Rabbinge (TPE-LUW) for helpful criticism on the manuscript, to ing. I. Ouwerkerk, who collected an important part of the data sets and did a lot of the preliminary simulation work, and to the colleagues of the JFBT- and MCB-networks, who offered the crop and weather data of their trials: Dr D.A. Bond, Cambridge (UK); Dr G. Duc, Dijon (F); Dr E. Ebmeyer, Göttingen (G); Dr P. Flengmark, Roskilde (D); Dr P.D. Hebblethwaite, Nottingham (UK); Dr E. von Kittlitz, Hohenheim (G); Dr D.K.L. MacKerron, Dundee (UK); Dipl. Ing. K. Mechtler, Wien (A); Ing. D.A. van der Schans, Lelystad (NL).

\section{References}

Dantuma, G., E. von Kittlitz, M. Frauen \& D.A. Bond, 1983. Yield, yield stability and measurements of morphological and phenological characters of faba bean (Vicia faba L.) varieties grown in a wide range of environments in Western Europe. Zeitschrift für Pflanzenzüchtung 90: $85-105$

Driessen, P.M., 1986. The water balance of the soil. In: H. van Keulen \& J. Wolf (Eds), Modelling 


\section{WATER SUPPLY ON VICIA FABA L. 4.}

of agricultural production: weather, soils and crops, p. 182-193. Pudoc, Wageningen.

Doorenbos, J., \& A.H. Kassam, 1979. Actual evapotranspiration. FAO irrigation and drainage paper 33. FAO, Rome, 193 pp.

Ebmeyer, E., 1984. Results of the Joint Faba Bean Trials of the years 1980-1982. In: P.D. Hebblethwaite, T.C.K. Dawkins, M.C. Heath \& G. Lockwood (Eds), Vicia faba: agronomy, physiology and breeding, p. 169-176. Martinus Nijhoff/Dr. W. Junk Publishers, The Hague.

Feddes, R.A., P.J. Kowalik, \& H. Zaradny, 1978. Simulation of field water use and crop yield. Pudoc, Wageningen, 189 pp.

Grashoff, C., 1990a. Effect of pattern of water supply on Vicia faba L. 1. Dry matter partitioning and yield variability. Netherlands Journal of Agricultural Science 38: 21-44.

Grashoff, C., 1990b. Effect of pattern of water supply on Vicia faba L. 2. Pod retention and filling, and dry matter partitioning, production and water use. Netherlands Journal of Agricultural Science 38: 131-143.

Grashoff, C. \& D.R. Verkerke, 1991. Effect of pattern of water supply on Vicia faba L. 3. Plant water relations, expansive growth and stomatal reactions. Netherlands Journal of Agricultural Science 39: 247-262.

Hsiao, T.C., E. Fereres, E. Acevedo, \& D.W. Henderson, 1976a. Water stress and dynamics of growth and yield of crop plants. In: O.L. Lange, L. Kappen \& E.D. Schulze (Eds), Water and Plant Life, p. 281-305. Springer Verlag, Berlin.

Hsiao, T.C., E. Acevedo, E. Fereres, \& D.W. Henderson, 1976b. Stress metabolism: water stress, growth and osmotic adjustment. Philosophical Transactions of the Royal Society of London B. 273: 479-500.

Jansen, D.M. \& P. Gosseye, 1986. Simulation of growth of millet (Pennisetum americanum) as influenced by waterstress. Simulation Reports CABO-TT 10, Wageningen. $108 \mathrm{pp}$.

Kropff, M., 1989. Quantification of SO2 effects on physiological processes, plant growth and crop protection. Ph D thesis Agricultural University, Wageningen, $201 \mathrm{pp}$.

Penning de Vries, F.W.T., D.M. Jansen, H.F.M. ten Berge \& A. Bakema, 1989. Simulation of ecophysiological processes of growth of several annual crops. Pudoc, Wageningen, $271 \mathrm{pp}$.

Roughly, R.J., J.I. Sprent \& J.M. Day, 1983. Nitrogen fixation. In: P.D. Hebblethwaite (Ed.), The faba bean, p. 233-260. Butterworths, London.

Shamsun Noor, L., C. Robin, D. Schontz, T. Heulin \& A. Guckert, 1989. Effet d'un déficit hydrique sur le trèfle blanc (Trifolium repens L.). I. Importance du cultivar. Agronomie 9: $251-257$.

Spitters, C.J.T., H. van Keulen \& D.W.G. van Kraalingen, 1989. A simple and universal crop growth simulator: SUCROS87. In: R. Rabbinge, S.A. Ward \& H.H. van Laar (Eds), Simulation and systems management in crop protection, p. 147-181. Pudoc, Wageningen.

Van der Schans, D.A. \& W. van den Berg, 1991. Opbrengstvariabiliteit bij erwten en veldbonen. PAGV verslag 121, PAGV, Lelystad, 104 pp.

Van Heemst, H.D.J., 1986. The distribution of dry matter during growth of a potato crop. Potato Research 29: 55-66.

Van Keulen, H., 1975. Simulation of water use and herbage growth in arid regions. Pudoc, Wageningen, $175 \mathrm{pp}$.

Van Keulen, H., N.G. Seligman \& J. Goudriaan, 1975. Availability of anions in the growth medium to roots of an actively growing plant. Netherlands Journal of Agricultural Science 23: 131-138.

Van Keulen, H., 1986. A simple model of water-limited production. In: H. van Keulen \& J. Wolf (Eds), Modelling of agricultural production: weather, soils and crops, p. 130-152. Pudoc, Wageningen.

Van Keulen, H. \& N.G. Seligman, 1987. Simulation of water use, nitrogen nutrition and growth of a spring wheat crop. Pudoc, Wageningen, 310 pp.

Vertregt, N. \& F.W.T. Penning de Vries, 1987. A rapid method for determining the efficiency of biosynthesis of plant biomass. Journal of Theoretical Biology 128: 109-119.

Woodhead, T., H.F.M. ten Berge \& A.M. de San Agustin, 1991. Modeling upland rice hydrology. IRRI research paper series, special on modeling (in press). 